\title{
AZ ALFÖLDI SZÉLENERGIA-POTENCIÁL VIZSGÁLATA
}

\section{INVESTIGATION OF WIND ENERGY POTENTIAL IN THE GREAT HUNGARIAN PLAIN}

\author{
Kostyák Attila ${ }^{1}$, Szodrai Ferenc ${ }^{2}$ \\ Debreceni Egyetem Müszaki Kar Épületgépészeti és Létesitménymérnöki Tanszék \\ 4028, Debrecen, Ótemetö utca 2-4. Tel.: +36-52-415-155/77770. \\ Iattila.kostyak@univerza.hu \\ ${ }^{2}$ szodrai@eng.unideb.hu
}

\begin{abstract}
Our goal was to see the possibilities of harnessing wind energy from places were the wind energy potential are low such as cities in the Great Hungarian Plain. For our calculations we have chosen Hajdúszoboszló. In our paper we used the wind data from the airport of Hajdúszoboszló. Analyzing the information; we created a Weibull distribution function by iterating of the function parameters with the wind velocity. After the wind distribution study, we examined the potential wind energy. When the wind conditions were taken into consideration, we made an assumption for choosing a common type of wind turbine. The disadvantages were gathered of these types and we assumed that an alternative wind turbine needed. Which research is required.
\end{abstract}

Keywords: wind energy, renewable energy, low air speed.

\section{Összefoglalás}

Vizsgálataink célja, hogy áttekintsük a szélenergia hasznosítás lehetőségét, olyan kevésbé elönyös szélrajzzal rendelkező területeken, mint az alföldi városok. Szemléltető példaként Hajdúszoboszló városát választottuk. A vizsgálataink során a hajdúszoboszlói reptér széladatait használtuk fel. A széladatok elemzése során az adatsorunkat Weibull eloszlással becsültük, paramétereit iterálással határoztuk meg. A széleloszlás vizsgálata után a potenciális szélenergiát vizsgáltuk meg. A szélviszonyok és a városias környezet állította feltételeket figyelembe véve arra a következtetésre jutottunk, hogy egyik turbina típus sem képes tökéletesen kielégíteni azokat. A feltételek figyelembe vételével egyedi szélturbina fejlesztése szükséges. Melynek fejlesztése jelenleg is zajlik.

Kulcsszavak: szélenergia, megújuló energia, alacsony szélsebesség.

\section{Bevezetés}

Vizsgálataink célja, hogy áttekintsük a szélenergia hasznosítás lehetőségét, olyan kevésbé előnyös szélrajzzal rendelkező területeken, mint az alföldi városok. Szemléltető példaként Hajdúszoboszló városát választottuk. A vizsgálataink során a hajdúszoboszlói reptér széladatait használtuk fel.

Napjainkban a megújuló energiaforrások kiaknázása kiemelt fontosságú. A nagy széltelepek, vízi erőmüvek és napelem telepek mellett, egyre gyakrabban láthatunk olyan méretü és kialakítású rendszereket, 
amelyek a megújuló energiák létesítményszintü termelését és felhasználását teszik lehetővé.

A létesítmény szinten telepíthető eszközök megjelenésével a lakossági és üzleti világ számára is elérhető alternatívává vált az energiatermelés lehetősége. Ennek a szemléletnek köszönhetően az alkalmazható eszközök fejlesztése és a lakókörnyezetbe való integrálása folyamatosan zajlik.

A városi és város közeli területeken napkollektorok és napelemek mellett egyre több helyen találhatóak kis szélerőmüvek is. Az Alföldön e berendezések elterjedését a kedvezőtlen feltételek akadályozzák.

Dolgozatunkban a létesítmény szinten alkalmazható berendezések problémakörét tekintem át. A problémák vázolásával láthatóvá válik, hogy mi a gátja e rendszerek elterjedésének, illetve melyek azok a problémák, amelyek a gyártmányfejlesztéssel kiküszöbölhetők.

\section{Szélviszonyokról általánosan}

A Nagy-Alföld szélrajzáról általánosan elmondható, hogy nem lehet meghatározni egyetlen uralkodó szélirányt. A szélmozgásokat erőteljesen befolyásolják a kontinensen egymást váltó ciklonok és anticiklonok. A ciklonok és anticiklonok által kialakult légmozgásokra jellemző, hogy erejük és irányuk is igen változékony.[1]

Az átlagos szélsebesség a Nagy-Alföld egész területén mérsékelt, körülbelül 3-3.5 $\mathrm{m} / \mathrm{s}$ körül ingadozik a tájegység egészén.[2]

Vizsgálatunk a városias környezetben létesítmény szinten üzemeltethető szélerőmüvekkel foglalkozik, ezért a természetes és mesterséges domborzat nagy szerepet játszik a szélerőmü telepítési helyén uralkodó szélviszonyokra.

A fentiek miatt az alföldi területeken a telepítés helyét fontos pontosan felmérni, mivel a szélviszonyok lokálisan is eltérhetnek a számunkra érdekes talaj közeli erömütípusoknál.
Dolgozatunkban a hajdúszoboszlói reptér széladatait használtam fel [3]. A reptér közvetlenül a város északi szélén található. A szélmérő berendezés a repülőtér irányítótornyán $9 \mathrm{~m}$ magasan helyezkedik el. Ez a magasság megfelelő lehet egy kis szélerőmü telepítésére, így ezzel az értékkel számoltam.

\section{Széladatok vizsgálata}

A reptér széladatait 2011.01.01-től 2015.10.03-ig vizsgáltuk. Az adatbázisban 3 órás intervallumok átlagos szélsebessége volt rögzítve, így a vizsgálat során a kis időintervallumokon mért szélerősség volatiltását nem állt módunkban felmérni.

$\mathrm{Az}$ adatbázis általános értékeit az alábbi 1. táblázat foglalja össze:

1.táblázat. Hajdúszoboszlói reptér széladatok 2011-2015

\begin{tabular}{|l|r|}
\hline Megfigyelések száma & $13895[\mathrm{db}]$ \\
\hline Átlagos szélsebesség & $3,2[\mathrm{~m} / \mathrm{s}]$ \\
\hline Medián & $2,9[\mathrm{~m} / \mathrm{s}]$ \\
\hline Maximum (3h átlag) & $12,8[\mathrm{~m} / \mathrm{s}]$ \\
\hline Minimum (3h átlag) & $0[\mathrm{~m} / \mathrm{s}]$ \\
\hline
\end{tabular}

A vizsgált időszakban előforduló értékek gyakoriságát az alábbi diagramon ponttokkal jelöltem százalékos formában.

$\mathrm{Az}$ értékek gyakoriságát a Weibull eloszlás sürüségfüggvényével közelítettem.

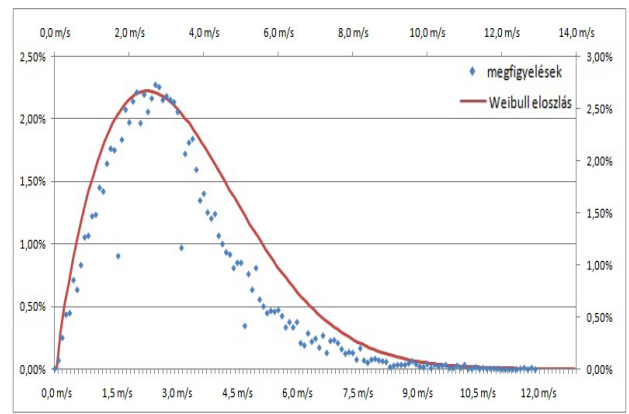

1. ábra. Szélsebesség-sebességgyakoriság és Weibull eloszlás függvénye 
A becslőfüggvény (Weibull sürüségfüggvény):

$$
f(x ; \lambda, k)= \begin{cases}\frac{k}{\lambda}\left(\frac{z}{\lambda}\right)^{h-1} e^{-(x / \lambda)^{h}} & x \geq 0, \\ 0 & x<0,\end{cases}
$$

A becslöfüggvény $k$ alak és $\lambda$ skalár paramétereit az alábbi módon határoztuk meg:

$\mathrm{Az}$ eloszlás várható értékét a vizsgált adatsor súlyozott átlagának értékében határoztam meg $(3,2[\mathrm{~m} / \mathrm{s}])$.

A becslö függvény várható értéke függ $k$ és $\lambda$ paraméterektől:

$$
\mathrm{E}(X)=\lambda \Gamma\left(1+\frac{1}{\bar{k}}\right)
$$

Ebből $\lambda$ paramétert kifejezve egy olyan összefüggést kapunk, ami csak $k$-tól függ

A $k$ érték meghatározását iterálással végeztem. Feltételeztem, hogy a mért és a becsült adatsor értékeiből származtatott egységnyi felületre kiszámított energiamennyiség átlagának is meg kell egyeznie.

$k$ értékének meghatározása után $\lambda$ értéke is meghatározhatóvá vált. A kapott értékek:

2.táblázat. Meghatározott eredmények

\begin{tabular}{|l|r|}
\hline Paraméter & Számított érték \\
\hline $\mathrm{k}$ alakparaméter & 1,7811 \\
\hline $\boldsymbol{\lambda}$ skalár & 3,5965 \\
\hline
\end{tabular}

A paraméterek meghatározása után megvizsgáltam a két adatsor korrelációját. Melynek értéke: 0,97.

A becslőfüggvénynek köszönhetően matematikai összefüggést kaptunk az általunk vizsgált terület szélviszonyaira vonatkozóan.

\section{Energiapotenciál vizsgálata}

A széladatok vizsgálata után tekintsük át, mekkora az energia potenciál a mérési ponton.

A széleloszlást becslő sürüségfüggvény segítségével kiszámolható a teljes vizsgált időszak alatt egységnyi felületen a szél potenciális munkavégző képessége.

A 2. ábrán látható a vizsgált időszakban a széleloszlás, valamint a vizsgált időszak alatt fújó különböző erősségű szelek potenciális munkavégző képessége. Az adott szélerősség melletti potenciális munkavégző képesség megállapításánál az adott szélerősség gyakoriságát is figyelembe vettük, így alakult ki az alábbi görbe.

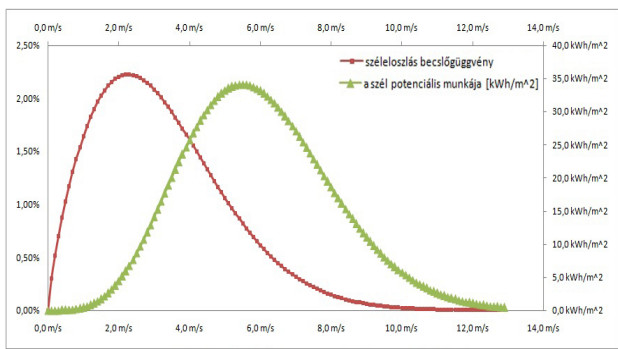

2. ábra. Weibull eloszlás és fajlagos szélenergia-szélsebesség diagram

Az optimális szélturbina kiválasztásánál a célunk, hogy olyan hatásfokgörbével rendelkezö turbinát válasszunk, hogy a lehető legnagyobb területet fedje le a szél potenciális munkájának görbe alatti területéböl.

$\mathrm{Az}$ eredmények alapján látható, hogy olyan szélturbinára van szükségünk, amely a hatékonysági görbéjének csúcspontját az 5-6 m/s szelek esetén éri el. Ebben az esetben tudjuk - a vizsgált időszak szélviszonyai között - a szél potenciális energiájából a lehetö legtöbbet hasznosítani.

Az energetikai optimalizáció következménye, hogy az adott szélviszonyok mellett a vizsgált időszak egy jelentős részében a turbina nem vagy csak rossz hatékonysággal termel energiát. A térség szélrajzának problémáját az alábbi példával lehet szemléltetni.

Ha feltesszük, hogy az energetikai görbénk alsó 10\%-a az 5-6 m/s-os szélsebességre optimalizált turbinánk számára nem hasznosítható, akkor a vizsgált időszak túl- 
nyomó részében a turbina nem termel energiát.

A 10\%-os példa esetén a turbinánk 3,3 $\mathrm{m} / \mathrm{s}$ szélsebesség mellett kezd el termelni, ami azt jelenti, hogy a turbina a vizsgált időszak 58\%-ban nem termelt volna hasznosítható energiát.

Tehát a maximum energia kinyerése és az egyenletes termelési görbe célja nincs összhangban. Itt a kiszolgálandó létesítmény tulajdonságai határozzák meg azt, mennyiben tér el a tervezett szélturbina az energetikailag optimálistól.

\subsection{Miért érdekes a hatékonyság?}

Megújuló energiaforrásokat hasznosító berendezéseknél lehetőség van arra, hogy az eszköz rossz hatékonyságát méretének növelésével kompenzáljuk.

Ez a lehetőség peremfeltételeim miatt nem jöhet szóba a szélturbina esetén.

A szélenergia hasznosítása városias környezetben igényli a lehető legkisebb méretet, ezáltal a lehető leghatékonyabb rendszert.

\subsection{Szélturbina városias környezet- ben}

A város közeli, létesítmény szintü szélenergia felhasználás több kihívást is állít a kialakítandó rendszer elé.

A fentiek alapján a rendszernek a lehető leghatékonyabbnak kell lennie, mivel méretének növelése rontja a rendszer integrálhatóságát.

A hatékonyság figyelembevételével a függőleges tengelyü szélturbinák nem javasol- hatóak, mert bár egyszerübb kialakításúak és kis szélsebesség esetén is elindulnak, lényegesen nagyobb felületre van szükségük ugyanakkora teljesítmény leadásához.[4]

A turbina biztonságtechnikai és akusztikailag előnyös kidolgozása kiemelten fontos a lakosság közelsége miatt.

\section{Következtetések}

A fenti vizsgálatok alapján a piacon található létesítmény szinten alkalmazható eszközök közül kevés képes kielégítően müködni az adott szélviszonyok között.

Azok a típusok pedig, amik megfelelnek a szélviszonyoknak, a városi integrálhatóság kritériumait nem képesek teljes mértékben kielégíteni. Ezért szükségesnek érezzük egy újfajta szélerőmü típusnak a vizsgálatát és fejlesztését.

Jelenleg is kidolgozás alatt áll egy szélturbina rendszer, melynek elméleti kidolgozás előrehaladott. A szélcsatornás tesztek, illetve a prototípus kidolgozása, valamint a gyártmány fejlesztési kérdések megválaszolása zajlik.

\section{Szakirodalmi hivatkozások}

[1] Ledács Kis Aladár: $A$ szélenergia hasznositása, Bp: Müszaki Könyvkiadó. 1963. 30-32.o.

[2] OMSZ weboldala; Magyarország szélviszonyai; met.hu

[3] Windguru adatbázis; www.windguru.cz/hu

[4] Hagyományos és megújuló energiák; szerk.: Dr. Sembery Péter, Dr. Tóth László; Szaktudás kiadóház 2004; 7.2.2.; 338-343 